\title{
Carcinoma associated paraneoplastic peripheral neuropathies in patients with and without anti-onconeural antibodies
}

\author{
Jean-Christophe Antoine, Jean-François Mosnier, Léna Absi, Philippe Convers, \\ Jérôme Honnorat, Daniel Michel
}

\begin{abstract}
Objective-When to suspect a paraneoplastic disorder is a puzzling problem that has not recently been studied in a large series of patients referred for peripheral neuropathy.

Methods-From 422 consecutive patients with peripheral neuropathy, 26 were analysed who concomitantly had carcinoma but no tumorous infiltration, drug toxicity, or cachexia. Their clinical, pathological, and electrophysiological data were analysed according to the presence of anti-onconeural antibodies, the latency between presentation and cancer diagnosis, and the incidence of carcinoma in the corresponding types of neuropathy of the population of 422 patients.
\end{abstract}

Results-Seven patients (group I) had anti-onconeural antibodies (six anti-Hu, one anti-CV2) and 19 did not (groups IIA and $B$ ). In group I, subacute sensory neuropathy (SSN) was the most frequent but other neuropathies including demyelinating neuropathies were present. Patients in group II A had a short latency (mean 7.88 months), and a rapidly and usually severe neuropathy which corresponded in 11/14 to an established inflammatory disorder including neuropathy with encephalomyelitis, mononeuritis multiplex, and acute or chronic inflammatory demyelinating polyneuropathy (CIDP). Patients in group IIB had a long latency (mean 8.4 years) and a very chronic disorder corresponding in four of five to an axonal noninflammatory polyneuropathy. In this population, the incidence of carcinoma occurring with a short latency was $47 \%$ in sensory neuronopathy, $1.7 \%$ in GuillainBarré syndrome, $10 \%$ in mononeuritis multiplex and CIDP, and $4.5 \%$ in axonal polyneuropathy.

Conclusions-Paraneoplastic neuropathies associated with carcinoma are heterogeneous disorders. Neuropathies occurring with a long latency with tumours probably resulted from a coincidental association. Neuropathies which occurred within a few years of the tumour evolved rapidly and corresponded mostly to inflammatory disorders. As dysimmune neuropathies are probably paraneoplastic in a limited number of cases, patients with these disorders should probably not be investigated systematically for carcinoma in the absence of antionconeural antibodies, except when the neuropathy is associated with encephalomyelitis and probably with vasculitis. Questions remain concerning CIDP. (f Neurol Neurosurg Psychiatry 1999;67:7-14)

Keywords: paraneoplastic neurological syndromes; peripheral neuropathy; Guillain-Barré syndrome; chronic inflammatory demyelinating neuropathy

Depending on diagnostic criteria, up to $50 \%$ of patients with carcinoma develop peripheral neuropathy. ${ }^{1}$ Treatment toxicity, tumorous infiltration, metabolic disturbances, or terminal cachexia account for most cases. ${ }^{2}$ Paraneoplastic neuropathies are rare and heterogeneous disorders. ${ }^{3}$ Some of them are part of complex syndromes involving simultaneously the central (CNS) and peripheral nervous systems (PNS), the most frequent of which is subacute sensory neuronopathy/paraneoplastic encephalomyelitis (SSN/PEM). ${ }^{4}$ This disorder, when occurring with small cell lung cancer, is almost invariably associated with anti-Hu antibodies. ${ }^{5}$ Paraneoplastic syndromes associated with the other known anti-onconeural antibodies often involve the PNS, but the neuropathies are less characterised. ${ }^{6-10}$ Although attention has been mainly focused on antibody positive cases, there also exist true paraneoplastic neuropathies and no known antibodies. ${ }^{11}$ These cases are difficult to define because many of the previous reports did not use modern investigation methods, ${ }^{12}{ }^{13}$ and most of the recent studies concern single or few cases so that it is difficult to know which type of neuropathy should be investigated for cancer. We have therefore performed a study on 26 patients selected from 422 consecutive patients with peripheral neuropathy who developed their neurological disorder in association with carcinomas. This led us to discuss the classification of these neuropathies, their links with tumours, and when to investigate a patient with peripheral neuropathy for carcinoma.

\section{Material and methods}

PATIENT SELECTION

The patients were selected from the data bank of 422 consecutive patients investigated for peripheral neuropathy in the Department of Neurology of the University Hospital of SaintEtienne between 1987 and June 1998. Our Department is the referential centre for neurological diseases in an estimated population of 
Table 1 Clinical data for the seven patients with anti-onconeural antibodies (group I). Delay indicates the interval between the onset of neurological symptoms and cancer diagnosis. In every case, the neuropathy preceded the discovery of the tumour. The revised Rankin score is used to estimate the maximal deficit reached by the patients

\begin{tabular}{|c|c|c|c|c|c|c|}
\hline No & Sex/age & $\begin{array}{l}\text { Delay } \\
\text { (months) }\end{array}$ & Clinical manifestations & Rankin & Course & Electrophysiology \\
\hline 1 & $\mathrm{M} / 56$ & 23 & $\begin{array}{l}\text { Sensory > motor symmetric in four limbs } \\
\text { ataxia. Central nystagmus. Hearing loss. } \\
\text { Pain. Depressed tendon reflexes }\end{array}$ & 4 & Progressive & $\begin{array}{l}\text { Reduced or absent SAP. Normal SCV. } \\
\text { Reduced MAP, normal MCV. Reduced } \\
\text { interferential pattern }\end{array}$ \\
\hline 2 & $M / 56$ & 9 & $\begin{array}{l}\text { Sensory symmetric in four limbs. Pain. } \\
\text { Ataxia. Depressed tendon reflexes } \\
\text { nystagmus, temporal lobe epilepsy }\end{array}$ & 4 & Progressive & $\begin{array}{l}\text { Reduced SAP. Significantly reduced SCV } \\
(3.4 \mu \mathrm{V} \text { and } 29 \mathrm{~m} / \mathrm{s} \text { in ulnar nerves). } \\
\text { Almost normal MCV }\end{array}$ \\
\hline 3 & $M / 61$ & 8 & $\begin{array}{l}\text { Sensory }>\text { motor deficit asymmetric in } \\
\text { lower limbs. Areflexia. Pain. Digestive } \\
\text { obstruction }\end{array}$ & 3 & Subacute & $\begin{array}{l}\text { Absent SAP. Mildly reduced MCV in } \\
\text { lower limbs with TD. Reduced } \\
\text { interferential pattern }\end{array}$ \\
\hline 4 & $\mathrm{M} / 73$ & 8 & $\begin{array}{l}\text { Sensory }>\text { motor asymmetric in lower limbs. } \\
\text { Areflexia. Cerebellar ataxia }\end{array}$ & 3 & Subacute & $\begin{array}{l}\text { Absent SAP. Mildly reduced SCV. Mild } \\
\text { reduction of MAP and MCV reduced } \\
\text { interferential pattern }\end{array}$ \\
\hline 5 & $\mathrm{M} / 50$ & 2 & $\begin{array}{l}\text { Multifocal sensory and painful. Reduced } \\
\text { tendon reflex. Orthostatic hypotension }\end{array}$ & 2 & Subacute & $\begin{array}{l}\text { Absent or reduced SAP. Normal SCV } \\
\text { normal MCV. Normal electromyography }\end{array}$ \\
\hline 6 & $M / 65$ & 8 & $\begin{array}{l}\text { Asymmetric sensory }>\text { motor deficit in four } \\
\text { limbs. Pain. Ataxia. Memory loss }\end{array}$ & 4 & Progressive & $\begin{array}{l}\text { Reduced or absent SAP. Mildly reduced } \\
\text { MAP and MCV. Prolonged F waves. } \\
\text { Temporal dispersion in tibial nerves } \\
\text { Reduced interferential pattern }\end{array}$ \\
\hline 7 & $\mathrm{~F} / 62$ & 12 & $\begin{array}{l}\text { Sensory-motor deficit and areflexia in lower } \\
\text { limbs. Cerebellar ataxia orthostatic } \\
\text { hypotension }\end{array}$ & 4 & Progressive & $\begin{array}{l}\text { Reduced SAP and SCV. Reduced MAP. } \\
\text { Mildly reduced MCV. Reduced } \\
\text { interferential pattern }\end{array}$ \\
\hline
\end{tabular}

Course corresponds to the onset of neurological symptoms: acute, $<1$ month; subacute 1-2 months; progressive, $>2$ months; CSF=number of lymphocytes/mm ${ }^{3}$; $\mathrm{ND}=$ not done; $\mathrm{SCLC}=$ small cell lung carcinoma; $\mathrm{SAP}=$ sensory action potential; $\mathrm{SCV}=$ sensory conduction velocities; $\mathrm{MAP}=$ motor action potentials; $\mathrm{MCV}=\mathrm{motor}$ conduction velocities.

500000 inhabitants. The selection criteria for the study were the presence of a clinically overt peripheral neuropathy, occurrence of a carcinoma proved by pathology or probable from radiological data, the simultaneous presence, at least at one time during the course, of both the neurological syndrome and the tumour, the absence of tumour infiltration, treatment toxicity, cachexia, or other known causes of peripheral neuropathy, and the availability of a serum sample for the research of anti-onconeural antibodies. The erythrocyte sedimentation rate, blood cell count, ionogram, blood glucose concentration, serum protein immunoelectrophoresis, and concentrations of creatinine, TSH, ANA, cholesterol, Apo A and B, vitamin $\mathrm{B}_{12}$, and folate were at least determined. Cytological examination of the CSF was performed after cytocentrifugation and showed the absence of tumour cells. The course was considered as being acute when the maximal deficit was reached within 1 month, subacute within 2 months, chronic when longer than 2 months, and relapsing when relapses occurred spontaneously and independently from immunosuppressive treatments. The motor deficit was graded using the Medical Research Council scale and the disability by the modified Rankin score. ${ }^{14}$ Follow up was defined by the latency between the onset of the neuropathy and the last consultation. In addition, after reviewing the data of the 422 patients with peripheral neuropathy, we estimated the incidence of carcinoma in different types of neuropathy in comparison with published series.

ELECTROPHYSIOLOGICAL STUDY

Needle examination was performed and sensory and motor conduction velocities measured in the upper and lower limbs, using the methods described by Kimura et al..$^{15}$ Routinely, the median and ulnar nerves were stimulated at the elbow and wrist, and the tibial and peroneal nerves at the knee and ankle. When a demyelinating process was suspected, the median and ulnar nerves were also studied after stimulation at the Erb point and the axilla. The electrophysiological data were considered as indicative of a primary demyelinating neuropathy when they fulfilled the criteria established by the ad hoc subcommittee for the diagnosis of chronic inflammatory demyelinating polyneuropathy (CIDP). ${ }^{16} \mathrm{~A}$ significant reduction with normal duration of the sensory and motor action potentials (SAPs and MAPs), and slowing of conduction velocities not exceeding $80 \%$ of the lower limit of normal were considered as indicative of an axonal neuropathy. A neuronopathy (involvement of motor neurons in anterior horn or sensory ganglionopathy) was suspected when a significant reduction with normal duration of the SAP or MAP, and normal conduction velocities occurred. In addition, needle EMG evidence of fibrillation potentials, positive sharp waves, or fasciculations were required for the diagnosis of motor neuron involvement.

\section{NEUROPATHOLOGICAL STUDY}

Samples of superficial peroneal nerve biopsies (18 cases) were fixed in 10\% formalin, embedded in paraffin, and stained with haematoxylin and eosin. Others were fixed in $2.5 \%$ glutaraldehyde, then in osmium tetroxide for semithin and ultrathin sections and for teased fibre examination. Muscle biopsies (six cases) were processed for paraffin, semithin, and ultrathin sections as nerve biopsies. For postmortem examination (four cases), the brain, spinal cord, certain lumbar sensory ganglia, and samples of peripheral nerves and muscles were fixed in $10 \%$ formalin; in addition, the L 5 sensory ganglion and samples of the left L5 ventral and dorsal roots, sciatic nerve, and common peroneal nerve at the level of the knee were removed and processed as for nerve biopsy.

SCREENING FOR ANTI-ONCONEURAL ANTIBODIES A serum sample was obtained from each patient and stored at $-80^{\circ} \mathrm{C}$ until required. 
Table 1 continued

\begin{tabular}{|c|c|c|c|}
\hline CSF & Tumour & Pathology & Antibody \\
\hline $2.0 \mathrm{~g} / 154$ lympho & SCLC & $\begin{array}{l}\text { Nerve biopsy, fibre loss, axonal } \\
\text { degeneration }\end{array}$ & Anti-Hu \\
\hline $1.14 \mathrm{~g} / 143$ lympho & SCLC & $\begin{array}{l}\text { Nerve biopsy, fibre loss, axonal } \\
\text { degeneration }\end{array}$ & Anti-Hu \\
\hline $0.42 \mathrm{~g} / 11$ lympho & SCLC & Nerve biopsy, fibre loss & Anti-Hu \\
\hline $0.78 \mathrm{~g} / 11$ lympho & $\begin{array}{l}\text { Small cell carinoma } \\
\text { prostate }\end{array}$ & $\begin{array}{l}\text { Nerve biopsy, axonal } \\
\text { degeneration }\end{array}$ & Anti-Hu \\
\hline $1.2 \mathrm{~g} / 11$ lympho & SCLC & ND & Anti-Hu \\
\hline $1.62 \mathrm{~g} / 152$ lympho & SCLC & $\begin{array}{l}\text { Necropsy: mild ganglionitis, } \\
\text { fibre loss in distal nerves. } \\
\text { Demyelination, onion bulbs } \\
\text { endoneurial lymphocytes }\end{array}$ & Anti-Hu \\
\hline $0.77 \mathrm{~g} / 117$ lympho & $\begin{array}{l}\text { Undifferentiated } \\
\text { carinoma } \\
\text { mediastinum }\end{array}$ & $\begin{array}{l}\text { Necropsy: normal sensory } \\
\text { ganglia and spinal cord. Fibre } \\
\text { loss demyelinated fibers }\end{array}$ & Anti-CV2 \\
\hline
\end{tabular}

Screening for anti-onconeural antiantibodies (anti-Hu, anti-Ri, anti-Yo, anti-amphyphysin, and anti-CV2) was performed by immunohistochemistry and western blotting experiments on rat brain in accordance with the guidelines recommended for their detection, ${ }^{17}$ using paraformaldehyde fixed sections of rat cerebellum, as described elsewhere. ${ }^{9}$ Positivity for antionconeural antibodies was confirmed by western blotting using the recombinant $\mathrm{HuD}, \mathrm{CDR}$ 62 proteins kindly provided by Dr J Dalmau (Sloan-Kettering Cancer Center, New York, USA), and the recombinant amphiphysin protein kindly provided by Professor P DeCamilli (Yale University, New Haven, USA) and for anti-CV2 antibodies with an S3 subcellular fraction of new born rat brain proteins. ${ }^{9}$

\section{Results}

Twenty six patients were selected for the study. None of them, except patient 17, had received chemotherapy before the onset of the neuropathy but the disorder (demyelinating Guillain-Barré syndrome) was not consistent with drug toxicity. Results from four of these patients have been published in full detail elsewhere. ${ }^{18} 19$ Seven patients had antionconeural antibodies (group I) and 19 did not (group II). Except in group I, the patients were not systematically investigated for cancer and the tumours were diagnosed when clinically apparent.

GROUP I: PATIENTS WITH ANTI-ONCONEURAL ANTIBODIES (SEVEN PATIENTS)

The neuropathy preceded the discovery of the cancer by 2 to 23 months (mean 10.00 months, table 1) and was usually severely disabling (Rankin score at 3 or 4 in six of seven patients) within a few months. Patients 1 to 6 had anti-Hu antibodies and small cell carcinoma of lung or prostate. Patient 7 had mediastinal undifferentiated carcinoma and anti-CV2 antibodies which reacted with a unc- 33 related and developmentally regulated protein. ${ }^{90-22} \mathrm{~Pa}-$ tients with anti-Hu antibodies had a subacute or rapidly progressive neuropathy that was sensory in two and sensory-motor but predominantly sensory in four. Symptoms of PEM were present in four of six. Two patients had dysautonomy. The sensory neuropathy had the clinical and electrophysiological characteristics of SSN in five of six cases. The last patient had a significant reduction of SCV (below $70 \%$ of lower limits of normal) with mild reduction of SAP. The study of motor conduction velocities (MCVs) was consistent with a mild axonal neuropathy in half of the cases. Electromyographic indications of a motor neuron disorder were never seen even when motor deficit was present. Two patients had additional unusual features suggestive of a mildly demyelinating neuropathy superimposed on the sensory neuropathy. This was confirmed by necropsy in one of them. ${ }^{19}$ In the other patients, nerve biopsy showed fibre loss and Wallerian degeneration without inflammatory changes. The patient with anti-CV2 antibodies had a mild sensory-motor neuropathy and cerebellar ataxia. Electrophysiology was consistent with an axonal neuropathy. At necropsy, dorsal root ganglia and anterior horns were normal. In the nerves, fibre loss was present and some fibres were undergoing axonal degeneration. Other fibres had a thin myelin sheath and some were undergoing demyelination. Inflammatory changes were absent. None of the patients in group I improved with steroids, plasma exchanges, or intravenous immunoglobulins.

GROUP II: PATIENTS WITHOUT ANTI-ONCONEURAL ANTIBODIES (19 PATIENTS)

The characteristics of the neuropathy and the associated cancers are summarised in tables 2 and 3. Patients in this group had very different types of carcinoma. The neuropathies were heterogeneous and can be divided into four types.

(1) In four patients (8-11), a sensory or sensory-motor neuropathy was associated with signs of corticospinal involvement suggesting that PEM was present. This was confirmed by postmortem examination in cases 8 and 9 . Electrophysiology was axonal (9 and 10) or neuronal (8 and 11). Inflammatory changes were present in the CSF of three of four of these patients. In the peripheral nerves, biopsies or necropsies showed fibre loss and Wallerian degeneration. Lesions were marked in patients 8,10 , and 11 , and mild in patient 9 . Mononuclear cell infiltrates were present in the endoneurium and around epineurial vessels in patients 8 and 11 .

(2) In two patients (12 and 13), the neuropathy presented as mononeuropathy multiplex (MNM) with systemic or nerve restricted non-necrotising vasculitis. Patient 13 had orthostatic hypotension.

(3) Seven patients (patients 14 to 16 and 22 to 25) had a sensory motor neuropathy that was electrophysiologically axonal. Nerve biopsy performed in three showed chronic axonal neuropathy without inflammatory changes. In the others, who did not have a pathological study, the possibility of metastatic involvement 
Table 2 Clinical data for the 14 patients with a short delay between the onset of the neuropathy and the discovery of the tumour who had no anti-onconeural antibodies (group IIA). Delay indicates the interval between the onset of neurological symptoms and cancer diagnosis and is expressed in months $(m)$ or weeks $(w)$. In every case, except case 13, the neuropathy preceded the discovery of the tumour. The revised Rankin score is used to estimate the maximal deficit reached by the patients

\begin{tabular}{|c|c|c|c|c|c|c|c|c|c|c|}
\hline No & Sex/age & Delay & $\begin{array}{l}\text { Clinical } \\
\text { manifestations }\end{array}$ & Course & Rankin & $\begin{array}{l}\text { Electro- } \\
\text { physiology }\end{array}$ & $C S F$ & Tumour & Pathological study & $\begin{array}{l}\text { Treatments } \\
\text { (neuopathy) }\end{array}$ \\
\hline 8 & $\mathrm{M} / 65$ & $3 \mathrm{~m}$ & $\begin{array}{l}\text { Proximal and distal } \\
\text { sensory motor } \\
\text { deficit, pain in four } \\
\text { limbs, diffuse } \\
\text { areflexia, } \\
\text { amyothrophia. } \\
\text { Respiratory } \\
\text { deficiency. Left } \\
\text { Babinski }\end{array}$ & Subacute & 5 & Neuronal & $\begin{array}{l}1.12 \mathrm{~g} / 111 \\
\text { lympho }\end{array}$ & Lung (CT) & $\begin{array}{l}\text { Inflammatory } \\
\text { ganglionitis and } \\
\text { myelitis, preservation } \\
\text { of motor neurons, } \\
\text { inflammatory lesions in } \\
\text { the nerves, necrotising } \\
\text { myopathy }\end{array}$ & $\begin{array}{l}\text { No } \\
\text { improvement } \\
\text { steroids PE } \\
\text { and IgIV }\end{array}$ \\
\hline 9 & $\mathrm{~F} / 71$ & $26 \mathrm{~m}$ & $\begin{array}{l}\text { Pain, paresthesia, } \\
\text { proximal > distal } \\
\text { motor deficit in } \\
\text { four limbs. Lower } \\
\text { limbs areflexia. } \\
\text { Bilateral Babinksi. } \\
\text { Reticular livedo }\end{array}$ & Progressive & 4 & Axonal & $\begin{array}{l}0.3 \mathrm{~g} / 11 \\
\text { lympho }\end{array}$ & $\begin{array}{l}\text { Pancreas } \\
\text { adenocarcinoma }\end{array}$ & $\begin{array}{l}\text { Mild inflammatory } \\
\text { ganglionitis and axonal } \\
\text { neuropathy, vessel } \\
\text { thickening, } \\
\text { inflammatory myositis }\end{array}$ & $\begin{array}{l}\text { No } \\
\text { improvement } \\
\text { steroids }\end{array}$ \\
\hline 10 & $\mathrm{M} / 73$ & $26 \mathrm{~m}$ & $\begin{array}{l}\text { Severe sensory > } \\
\text { motor deficit in } \\
\text { four limbs lower } \\
\text { limbs areflexia, } \\
\text { transient diplopia } \\
\text { bilateral Babinski }\end{array}$ & Progressive & 4 & Axonal & $\begin{array}{l}1.20 \mathrm{~g} / 135 \\
\text { lympho }\end{array}$ & SCLC lung & $\begin{array}{l}\text { Nerve biopsy: fibre } \\
\text { loss, axonal } \\
\text { degeneration, slight } \\
\text { inflammatory reaction, } \\
\text { normal muscle }\end{array}$ & $\begin{array}{l}\text { No } \\
\text { improvement } \\
\text { steroids PE } \\
\text { azat }\end{array}$ \\
\hline 11 & $\mathrm{M} / 74$ & $4 \mathrm{~m}$ & $\begin{array}{l}\text { Sensory motor } \\
\text { proximal and distal } \\
\text { deficit in four } \\
\text { limbs, amyotrophia, } \\
\text { normal tendon } \\
\text { reflexes, bilateral } \\
\text { Babinski }\end{array}$ & Progressive & 4 & Neuronal & $\begin{array}{l}2.02 \mathrm{~g} / 128 \\
\text { lympho }\end{array}$ & Urinary $(\mathrm{CT})$ & $\begin{array}{l}\text { Nerve biopsy: } \\
\text { multifocal axonal } \\
\text { lesions, endoneurial } \\
\text { inflammatory reaction } \\
\text { vasculitis. Muscle: } \\
\text { neurogenic atrophy }\end{array}$ & $\begin{array}{l}\text { No } \\
\text { improvement } \\
\text { steroids }\end{array}$ \\
\hline 12 & $\mathrm{~F} / 72$ & $6 \mathrm{~m}$ & $\begin{array}{l}\text { Mononeuropathy } \\
\text { multiplex. Peroneal } \\
\text { and tibial nerves } \\
\text { hypereosinophylia, } \\
\text { raised ESR, } \\
\text { sinusitis }\end{array}$ & Acute & 3 & Axonal & $\begin{array}{l}0.32 \mathrm{~g} / 11 \\
\text { lympho }\end{array}$ & $\begin{array}{l}\text { Colon } \\
\text { adenocarcinoma } \\
\text { (recidive) }\end{array}$ & $\begin{array}{l}\text { Nerve biopsy: axonal } \\
\text { degeneration, vasculitis } \\
\text { in a nasal polypoid } \\
\text { formation. Muscle: } \\
\text { neurogenic atrophy }\end{array}$ & $\begin{array}{l}\text { Improvement } \\
\text { steroids } \\
\text { (Rankin } 3 \text { to } \\
\text { 1) }\end{array}$ \\
\hline 13 & $M / 65$ & $2 \mathrm{w}$ & $\begin{array}{l}\text { Multifocal sensory } \\
\text { motor deficit in } \\
\text { right arm and lower } \\
\text { limbs. Leg areflexia. } \\
\text { Orthostatic } \\
\text { hypotension }\end{array}$ & Relapsing & 2 & Axonal & $\begin{array}{l}0.50 \mathrm{~g} / 11 \\
\text { lympho }\end{array}$ & $\begin{array}{l}\text { Tongue } \\
\text { epidermoid }\end{array}$ & $\begin{array}{l}\text { Nerve biopsy: fibre } \\
\text { loss, degenerating } \\
\text { fibres, epineural } \\
\text { vasculitis }\end{array}$ & $\begin{array}{l}\text { Spontaneous } \\
\text { improvement }\end{array}$ \\
\hline 14 & $\mathrm{M} / 84$ & $7 \mathrm{~m}$ & $\begin{array}{l}\text { Distal sensory } \\
\text { painful asymmetric } \\
\text { in four limbs, lower } \\
\text { limb areflexia }\end{array}$ & Subacute & 3 & Axonal & $\begin{array}{l}0.49 \mathrm{~g} / 11 \\
\text { lympho }\end{array}$ & $\begin{array}{l}\text { Lung } \\
\text { undiffentiated } \\
\text { adenocarcinoma }\end{array}$ & ND & $\begin{array}{l}\text { No } \\
\text { improvement } \\
\text { steroids }\end{array}$ \\
\hline 15 & $M / 85$ & $9 \mathrm{~m}$ & $\begin{array}{l}\text { Distal pain, sensory } \\
\text { loss and areflexia in } \\
\text { lower limbs }\end{array}$ & Progressive & 2 & Axonal & $\begin{array}{l}0.53 \mathrm{~g} / 11 \\
\text { lympho }\end{array}$ & Lung (CT scan) & ND & ND \\
\hline 16 & $\mathrm{M} / 61$ & $1 \mathrm{~m}$ & $\begin{array}{l}\text { Motor>sensory } \\
\text { asymmetric deficit } \\
\text { in four limbs, } \\
\text { fasciculations, } \\
\text { absent or reduced } \\
\text { tendon reflexes }\end{array}$ & Acute & 3 & Neuronal & $\begin{array}{l}0.30 \mathrm{~g} / 11 \\
\text { lympho }\end{array}$ & $\begin{array}{l}\text { Gastric } \\
\text { adenocarcinoma }\end{array}$ & $\begin{array}{l}\text { Neurogenic atrophy in } \\
\text { muscle }\end{array}$ & $\begin{array}{l}\text { No } \\
\text { improvement } \\
\text { steroids }\end{array}$ \\
\hline 17 & $\mathrm{M} / 48$ & $0 \mathrm{~m}$ & $\begin{array}{l}\text { Sensory motor } \\
\text { Guillain-Barré } \\
\text { syndrome, areflexia } \\
\text { in four limbs, facial } \\
\text { nerve palsy }\end{array}$ & Acute & 4 & Demyelinating & $\begin{array}{l}0.66 \mathrm{~g} / 11 \\
\text { lympho }\end{array}$ & $\begin{array}{l}\text { Tongue } \\
\text { epidermoid } \\
\text { (recidive) }\end{array}$ & $\begin{array}{l}\text { Nerve biopsy: ongoing } \\
\text { macrophage induced } \\
\text { demyelination }\end{array}$ & $\begin{array}{l}\text { Improvement } \\
\text { IgIV (Rankin } \\
4 \text { to } 2 \text { ) }\end{array}$ \\
\hline 18 & $\mathrm{M} / 73$ & $3 \mathrm{~m}$ & $\begin{array}{l}\text { CIDP. Sensory } \\
\text { motor mainly } \\
\text { proximal deficit } \\
\text { and areflexia in } \\
\text { four limbs }\end{array}$ & Progressive & 3 & Demyelinating & $\begin{array}{l}1.27 \mathrm{~g} / 11 \\
\text { lympho }\end{array}$ & $\begin{array}{l}\text { Pancreas } \\
\text { adenocarcinoma }\end{array}$ & ND & $\begin{array}{l}\text { Improvement } \\
\text { IgIV (Rankin } \\
3 \text { to } 2 \text { ) }\end{array}$ \\
\hline 19 & $\mathrm{M} / 73$ & $6 \mathrm{~m}$ & $\begin{array}{l}\text { CIDP. Sensory } \\
\text { motor mainly } \\
\text { proximal mainly } \\
\text { upper limbs deficit } \\
\text { and areflexia in } \\
\text { four limbs }\end{array}$ & Progressive & 2 & Demyelinating & $\begin{array}{l}0.90 \mathrm{~g} / 11 \\
\text { lympho }\end{array}$ & $\begin{array}{l}\text { Colon } \\
\text { adenocarcinoma }\end{array}$ & $\begin{array}{l}\text { Nerve biopsy: fiber } \\
\text { loss, remyelinated } \\
\text { fibers, onion bulb } \\
\text { formations, slight } \\
\text { inflammatory changes }\end{array}$ & $\begin{array}{l}\text { Improvement } \\
\text { after surgery } \\
\text { (Rankin } 2 \text { to } \\
\text { 1) }\end{array}$ \\
\hline 20 & $M / 61$ & $9 \mathrm{~m}$ & $\begin{array}{l}\text { CIDP. Mainly } \\
\text { motor } \\
\text { proximal>distal } \\
\text { deficit and areflexia } \\
\text { in four limbs }\end{array}$ & Progressive & 4 & Demyelinating & $\begin{array}{l}1.60 \mathrm{~g} / 11 \\
\text { lympho }\end{array}$ & $\begin{array}{l}\text { Liver } \\
\text { adenocarcinoma }\end{array}$ & $\begin{array}{l}\text { Nerve biopsy: almost } \\
\text { normal fibers } \\
\text { endoneurial } \\
\text { lymphocytes }\end{array}$ & $\begin{array}{l}\text { Improvement } \\
\text { steroid IgIV } \\
\text { azat (Rankin } \\
4 \text { to } 1 \text { ) }\end{array}$ \\
\hline 21 & $\mathrm{M} / 78$ & $+2 \mathrm{~m}$ & $\begin{array}{l}\text { Sensory motor } \\
\text { proximal and distal } \\
\text { deficit in four } \\
\text { limbs. Depressed or } \\
\text { abolished tendon } \\
\text { reflexes }\end{array}$ & Subacute & 5 & $\begin{array}{l}\text { Demyelinating } \\
+ \text { axonal }\end{array}$ & $\begin{array}{l}1.60 \mathrm{~g} / 11 \\
\text { lympho }\end{array}$ & $\begin{array}{l}\text { Prostate } \\
\text { adenocarcinoma }\end{array}$ & $\begin{array}{l}\text { Demyelinated fibers, } \\
\text { slight onion bulbs } \\
\text { degenerated fibers and } \\
\text { regenerating clusters } \\
\text { endoneurial } \\
\text { macrophages }\end{array}$ & $\begin{array}{l}\text { Improvement } \\
\text { steroids } \\
\text { (Rankin } 5 \text { to } \\
4 \text { ) }\end{array}$ \\
\hline
\end{tabular}

Course corresponds to the onset of neurological symptoms: acute, $<1$ month; subacute $1-2$ months; progressive, $>2$ months.. CIDP=chronic inflammatory demyelinating polyneuropathy; $\mathrm{TD}=$ temporal dispersion; $\mathrm{CB}=$ conduction block. $\mathrm{PE}=$ plasma exchanges. IgIV=intravenous immunoglobulins. azat $=$ azathioprine. When improvement occurred after immunotherapy, the Rankin score before and after treatment is given in parentheses. Other abbreviations are the same as in table 1 
Table 3 Clinical data for the five patients with a long delay between the onset of the neuropathy and the discovery of the tumour who had no anti-onconeural antibodies (group IIB)

\begin{tabular}{|c|c|c|c|c|c|c|c|c|c|}
\hline No & Sex/age & $\begin{array}{l}\text { Delay } \\
\text { (y) }\end{array}$ & Clinical manifestations & Course & Rankin & Electrophysiology & $C S F$ & Tumour & Pathological study \\
\hline 22 & $2 \mathrm{M} / 73$ & 5 & $\begin{array}{l}\text { Sensory loss in lower } \\
\text { limbs, lower limbs } \\
\text { areflexia }\end{array}$ & Progressive & 2 & $\begin{array}{l}\text { Axonal, reduced/absent } \\
\text { SAP, reduced MAP, mild } \\
\text { reduction of CV }\end{array}$ & $0.8 \mathrm{~g} / 11 \mathrm{lympho}$ & $\begin{array}{l}\text { Prostate } \\
\text { adenocarcinoma }\end{array}$ & $\begin{array}{l}\text { Nerve biopsy: fibre } \\
\text { loss, no inflammatory } \\
\text { changes }\end{array}$ \\
\hline 23 & $\mathrm{~F} / 71$ & 9 & $\begin{array}{l}\text { Pain, paresthesia, sensory } \\
\text { loss and areflexia in lower } \\
\text { limbs }\end{array}$ & Progressive & 1 & $\begin{array}{l}\text { Axonal, reduced } \\
\text { MAP/SAP. Mild } \\
\text { reduction of CV }\end{array}$ & $0.2 \mathrm{~g} / 11$ lympho & $\begin{array}{l}\text { Pancreas } \\
\text { adenocarcinoma }\end{array}$ & $\begin{array}{l}\text { Fibre loss, } \\
\text { regenerating clusters, } \\
\text { no inflammatory } \\
\text { changes }\end{array}$ \\
\hline 24 & $\mathrm{M} / 72$ & $4-5$ & $\begin{array}{l}\text { Distal sensory motor } \\
\text { deficit and areflexia in } \\
\text { lower limbs }\end{array}$ & Progressive & 2 & $\begin{array}{l}\text { Axonal, reduced/absent } \\
\text { SAP and MAP, mild } \\
\text { reduction M-S CV }\end{array}$ & $\begin{array}{l}0.67 \mathrm{~g} / 11 \\
\text { lympho }\end{array}$ & $\begin{array}{l}\text { Penis } \\
\text { epithelioma }\end{array}$ & $\begin{array}{l}\text { Nerve biopsy: severe } \\
\text { fibre loss, no } \\
\text { inflammatory changes }\end{array}$ \\
\hline 25 & $\mathrm{M} / 64$ & 14 & $\begin{array}{l}\text { Sensory motor distal } \\
\text { deficit and areflexia in } \\
\text { lower limbs }\end{array}$ & Progressive & 2 & $\begin{array}{l}\text { Axonal, reduced } \\
\mathrm{MAP} / \mathrm{SAP} \text {, mild } \\
\text { reduction of CV }\end{array}$ & $0.7 \mathrm{~g} / 11 \mathrm{lympho}$ & $\begin{array}{l}\text { Prostate } \\
\text { adenocarcinoma }\end{array}$ & ND \\
\hline 26 & $\mathrm{M} / 64$ & 10 & $\begin{array}{l}\text { CIDP. Mild paraesthesia } \\
\text { and motor deficit, } \\
\text { hyporeflexia in four limbs. } \\
\text { Hypertrophic nerves. } \\
\text { MGUS IgG }\end{array}$ & Progressive & 1 & $\begin{array}{l}\text { Demyelinating severely } \\
\text { reduced MCV, temporal } \\
\text { dispersion }\end{array}$ & $8.2 \mathrm{~g} / 11$ lympho & $\begin{array}{l}\text { Malignant } \\
\text { melanoma }\end{array}$ & $\begin{array}{l}\text { Nerve biopsy: } \\
\text { demyelinated fibres, } \\
\text { onion bulb formations }\end{array}$ \\
\hline
\end{tabular}

Abbreviations are the same as in table 2 . In all cases, the neuropathy preceded the diagnosis of cancer.

of peripheral nerves was low as CSF examination showed no tumour cells and patients were followed up several months or years after tumour diagnosis with stabilisation of the neuropathy.

(4) Six patients (patients 17 to 21 and 26) had an electrophysiological demyelinating neuropathy. In patient 17 , it was a typical GuillainBarré syndrome that occurred simultaneously with a rapidly lethal (within 3 months) recurrence of tongue carcinoma. The other patients had a CIDP-like neuropathy which conformed to the diagnostic criteria of the ad hoc subcommittee. ${ }^{18}$ Patient 21 had mixed axonal and demyelinating features on electrophysiology. Nerve biopsy showed fibre loss, regenerating clusters suggesting distal axonal degeneration, and demyelinated fibres, onion bulb formations, and endoneurial macrophages.

TYPE OF NEUROPATHY ACCORDING TO DELAY IN GROUP II

Patients in group II can be subdivided into two groups according to the delay between the onset of the neuropathy and the diagnosis of cancer. Group IIA consisted of 14 patients (table 2) in whom the delay was between 0-26, mean 7.88 months. They usually had a severe neuropathy (Rankin score $2-5$, mean 3.4 ) with either acute, subacute, progressive, or relapsing course. When progressive, the maximal disability was reached within 6 to 9 months. The neuropathy was sensory-motor in 12 of 14 patients and purely sensory in two. None of them had sensory ataxia. In 11 of 14 patients, the neuropathy corresponded to an established inflammatory disorder (SSN/EM, mononeuritis multiplex, Guillain-Barré syndrome, or CIDP). Immunosuppressive treatments were performed in 11 patients. Patients with CIDP or Guillain-Barré syndrome, and one patient with MNM improved. None of the patients with CNS involvement or non-specific axonal neuropathy improved. Group IIB (table 3) consisted of five patients in whom the delay varied from 4 to 14 (mean 8.4). years In all of them, the neuropathy was very slowly progressive and evolved over many years. The disabil- ity was minor (Rankin score 1 or 2 ). Four of these five patients had an axonal sensory motor polyneuropathy without inflammatory changes. The last patient had a very chronic and indolent CIDP. After 10 years, he developed malignant melanoma. He had no vitiligo and the research for anti-GM1, GD2, GD3, GM3, GD1a, and GD1b antibodies was negative.

INCIDENCE OF CARCINOMA ACCORDING TO THE TYPE OF NEUROPATHY

The 26 patients reported above represent $6.2 \%$ of the patients referred for the diagnosis of neuropathy and $9 \%$ of patients over 50 years of age. However, when taking into account only patients in whom the tumour appeared within 2.5 years, the distribution was different according to the type of neuropathy. Among our patients with sensory neuronopathy, $47 \%$ had a carcinoma. These patients usually had a subacute or rapidly progressive disorder with symptoms of PEM while patients without cancer had an isolated and slowly progressive neuropathy. Comparatively, one patient among 59 with Guillain-Barré syndrome (1.7\%) had carcinoma simultaneously. Patients with CIDP or mononeuritis multiplex, had almost the same incidence of carcinoma (10\%) and it was $4.5 \%$ in patients with axonal sensory-motor polyneuropathy of otherwise unknown origin.

\section{Discussion}

Contrary to studies originating from cancer centres, ${ }^{3}$ our population of patients was first referred to a department of neurology. This can explain why in our series, the neurological disorder usually preceded the diagnosis of tumour. None of the patients selected for the present study had cachexia, tumorous infiltration, or chemotherapy as the cause of the neuropathy suggesting that their disorders were paraneoplastic. Currently, the detection of high titres of one of the anti-onconeural antibodies is the best way to identify a neurological syndrome as paraneoplastic. We found one of them (mainly anti-Hu antibodies) in $28 \%$ of patients (group I) only. These patients had a subacute or rapidly progressive and usually 
severely disabling neurological disorder involving both the CNS and PNS in most of them. Although most patients with anti-Hu antibodies had $\mathrm{SSN}^{23}$ we also found axonal or demyelinating neuropathies in accordance with recent studies which indicate that neuropathies associated anti-Hu antibodies can be heterogeneous. ${ }^{24-27}$

In 19 of 26 patients, anti-onconeural antibodies were not detected. The neuropathies in this group (group II) were also heterogeneous, including neuropathy with encephelomyelitis, mononeuropathy multiplex, Guillain-Barré syndrome, CIDP, and axonal polyneuropathy. Although individual cases or small series of each of these disorders have been reported to depend on a remote effect of cancer, ${ }^{28-31}$ their paraneoplastic origin cannot be ascertained except when the neuropathy is associated with encephalomyelitis. ${ }^{5}$ In the absence of specific markers, arguments in favour of a remote effect of carcinoma can only be drawn from indirect criteria. In our study, we used (1) the latency between onset of the neuropathy and diagnosis of cancer, (2) the characteristics of the neuropathy, and (3) the incidence of cancer in the corresponding type of neuropathy.

In Lambert-Eaton myasthenic syndrome, the risk of cancer decreases sharply after 2 years and becomes extremely low at 4 years $^{32}$ showing that when a disorder is paraneoplastic, cancer becomes apparent within a relatively short delay. In our series, we clearly have two groups of patients. In the first (group IIA), the latency was short and comparable with that of patients with paraneoplastic antibodies ${ }^{62327}$ suggesting direct physiopathological links between tumour and neuropathy. In the second (group IIB), carcinoma appeared many years after the onset of the neuropathy, suggesting that it was a coincidental association. The number of patients in this group was relatively small but as protracted follow up over more than 5 years was obtained in a small proportion of our population only, several cases may have been missed in group IIB. Conversely, as most of our patients were followed up during the first years of the evolution of their neuropathy only a few patients had probably escaped in group IIA.

The characteristics of the neuropathies were different between group II A and B. Patients in group IIB had a very chronic, slowly progressive, and mildly disabling disorder as opposed to group IIA in which the neuropathies had a severe and rapid course. Interestingly, $78 \%$ of the neuropathies in group IIA correspond to a known inflammatory disorder of the PNS. This contrasts with patients with long latency who for the most part had a non-inflammatory axonal polyneuropathy. Only one of them developed an indolent CIDP which evolved over 10 years before the diagnosis of malignant melanoma. Recently, a particular association of CIDP and melanoma has been reported, possibly involving a shared immunoreactivity against gangliosides. ${ }^{33}$ However, our patient had no antiganglioside antibodies and differed from these cases by the delay of tumour diagnosis and the absence of vitiligo.

The pathophysiology of paraneoplastic neurological syndrome is not completely understood, but an increasing amount of data indicates that at least in patients with antionconeural antibodies dysimmune mechanisms are involved. ${ }^{5}$ The fact that in our series most of the neuropathies which occurred within 2.5 years with a carcinoma correspond to known inflammatory disorders suggests that despite the absence of specific antibodies or other known immunological markers, tumours have in some way induced the immunological perturbations underlying the neuropathies.

Each of the well established paraneoplastic neurological syndromes also occurs without cancer. Thus, $40 \%$ of patients with LambertEaton myasthenic syndrome do not have tumours. $^{32}$ The proportion is $50 \%$ in patients

Table 4 Incidence of carcinoma according to the type of neuropathy in our series and in several other published series

\begin{tabular}{|c|c|c|c|c|}
\hline Type of neuropathy (authors) & $\begin{array}{l}\text { Number } \\
\text { of cases }\end{array}$ & $\begin{array}{l}\text { Incidence of } \\
\text { carcinoma } \\
(\%)\end{array}$ & $\begin{array}{l}\text { Follow up } \\
\text { (mean value in } \\
\text { our study) }\end{array}$ & Commentaries \\
\hline \multicolumn{5}{|c|}{ General population of neuropathies } \\
\hline Prineas $e t a l^{35}$ & 278 & 5.4 & $>18$ months & \\
\hline Our study & 422 & 6.2 & ND & \\
\hline \multicolumn{5}{|l|}{ Guillain-Barré syndrome } \\
\hline Halls et $a l^{26}$ & 29 & 6.9 & $>400$ days & \multirow{3}{*}{$\%$ of death due to carcinoma within 250 days } \\
\hline Italian study group ${ }^{37}$ & 297 & 0.7 & 24 months & \\
\hline Our study^ & 59 & 1.7 & $<2 \mathrm{y}$ & \\
\hline \multicolumn{5}{|l|}{ CIDP } \\
\hline Barhon $e t a l^{8}$ & 60 & 5.0 & NS & \multirow{3}{*}{$\begin{array}{l}\text { These studies include patients with MGUS of } \\
\text { unknown reactivity }\end{array}$} \\
\hline Gorson et $a l^{39}$ & 67 & 0 & Mean 3 y & \\
\hline Our study^ & 38 & 10.5 & 5.7 y $(0.5-16)$ & \\
\hline \multicolumn{5}{|c|}{ Vasculitis/mononeuritis multiplex } \\
\hline Vincent $e t a l^{40}$ & 50 & 14 & NS & \multirow[t]{4}{*}{ Patients selected from nerve biopsies } \\
\hline Vincent $e t a l^{41}$ & 50 & 10 & NS & \\
\hline Harati et al $l^{42}$ & 33 & 9 & $\begin{array}{l}\text { Mean } 18.5 \\
\text { months }\end{array}$ & \\
\hline Our study^ & 20 & 10 & 2.3 y $(0.5-10)$ & \\
\hline \multicolumn{5}{|c|}{$\begin{array}{l}\text { Axonal polyneuropathy of otherwise } \\
\text { undetermined cause }\end{array}$} \\
\hline Fagius $e t a l^{43}$ & 91 & 1.0 & Mean $3.7 \mathrm{y}$ & \\
\hline McLeod et $a l^{44}$ & 47 & 10.6 & Median $3 \mathrm{y}$ & \\
\hline Notermans et $a l^{45}$ & 75 & 5.3 & $4.7 \mathrm{y}$ & Prospective study \\
\hline Camerlingo et al ${ }^{46}$ & 51 & 29.4 & $\begin{array}{l}\text { Mean } 51.4 \\
\text { months }\end{array}$ & $\begin{array}{l}\text { Prospective study of patients with pure } \\
\text { sensory neuropathy }\end{array}$ \\
\hline Our study* & 67 & 10.3 & 3.7 y $(0.3-11)$ & $4.5 \%$ within 2 years after onset \\
\hline
\end{tabular}

$\mathrm{ND}=$ not done; $\mathrm{NS}=$ not stated; MGUS=monoclonal gammopathy of unknown significance.

$\star$ Patients with a short latency are taken into account only. 
with subacute sensory neuropathy ${ }^{5}$ and around $80 \%$ in patients with dermatomyositis and polymyositis. $^{34}$ In our series, $9 \%$ of patients over 50 years of age with neuropathy developed carcinoma. There are only a few studies considering the problem of the incidence of carcinoma in peripheral neuropathy (see table 4), ${ }^{35-46}$ particularly when they are devoted to one type of neuropathy as patients with tumour are often excluded from these studies. When combining their results with ours, $5 \%$ to $15 \%$ of patients with neuropathy seem to develop carcinoma. As expected, the highest incidence is found with sensory neuronopathy. ${ }^{56}$ It is probably very low in Guillain-Barré syndrome and high (up to $15 \%$ ) in vasculitic neuropathy. Due to a lack of studies, data are less clear with CIDP, but our results indicate an incidence of $10 \%$. In patients with axonal polyneuropathy of otherwise unknown origin, only $4 \%-5 \%$ of patients develop cancer within the first years after the appearance of the neuropathy and an additional similar proportion with protracted follow up.

In conclusion, paraneoplastic neuropathies are heterogeneous disorders even in patients with anti-onconeural antibodies. In patients without antibodies, neuropathies which occurred within 2.5 years of carcinoma were probably paraneoplastic and corresponded mainly to inflammatory disorders whereas in neuropathies in which the cancer appeared after many years the association was probably coincidental. As dysimmune neuropathies are paraneoplastic in a limited number of cases, patients with these disorders should probably not be investigated systematically for carcinoma in the absence of anti-onconeural antibodies, except when the neuropathy is associated with encephalomyelitis and with vasculitis. Questions remain concerning CIDP.

We express our grateful thanks to Dr Josep Dalmau for reading the manuscript and giving useful criticism and advice.

1 Mc Leod JG. Paraneoplastic neuropathies. In: Dyck PJ, Thomas PK, eds. Peripheral neuropathy: Philadelphia: Saunders, 1993;II:1583-90.

2 Posner JB. Neurologic complications of cancer: Philadelphia: FA Davis, 1995

3 Smitt PS Posner JB. Paraneoplastic peripheral neuropathy. In: Latov N, Wokke JH, Kelly JJ, eds. Immunological and infectious diseases of the peripheral nerves. Cambridge: Cambridge tious diseases of the pripheral ner.

4 Henson RA, Urich H. Peripheral neuropathy associated with malignant disease. In: Vinken PJ, Bruyn GW, eds. Handbook malignant disease. In: Vinken PJ, Bruyn GW, eds. Handbook
of clinical neurology. Amsterdam: North-Holland, 1979;8: of clinical $131-48$.

5 Dalmau J, Posner JB. Paraneoplastic syndromes affecting the nervous system. Semin Oncol 1997;24:318-28.

6 Peterson K, Rosenblum MK, Kotanides H, et al. Paraneoplastic cerebellar degeneration; a clinical analysis of 55 anti-Yo antibody-positive patients. Neurology 1992:42 1931-7.

7 Konanc DA, O’Neil BP, Caselli RJ, et al. Peripheral neuropathic presentation in 3 patients with seropositivity for type 1 anti-Purkinje cell antibodies (PCA-1) and ovarian or related müllerian carcinoma. Neurology 1995;45(suppl 4):A320.

8 Hormingo A, Dalmau J, Rosenblum MK, et al. Immunological and pathological study of anti-Ri-associated encephalopathy. Ann Neurol 1994;36:896-902.

9 Honnorat J, Antoine JC, Derrington E, et al. Antibodies to a Honnorat J, Antoine JC, Derrington E, et al. Antibodies to a
subpopulation of glial cells and a $66 \mathrm{kD}$ developmental protein in patients with paraneoplastic neurological syndrome. $\mathcal{F}$ Neurol Neurosurg Psychiatry 1996;61:270-8.
10 Dropcho EJ. Antiamphiphysin antibodies with small-cell ung carcinoma and paraneoplastic encephalomyelitis. Ann Neurol 1996;39:659-67.

11 Graus F, René R. Paraneoplastic neuropathies. Eur Neurol 1993;33:279-86.

12 Henson RA, Russel DS, Wilkinson M. Carcinomatous neuropathy and myopathy. A clinical and pathological study. Brain 1954;77:82-120.

13 Croft PB, Urich H, Wilkinson M. Peripheral neuropathy of sensory motor type associated with malignant disease. Brain 1967;90:31-66.

14 Uchuya $M$, Graus F, Vega $F$, et al. Intravenous immunoglobulin treatment in paraneoplastic neurological syndromes with antineuronal autoantibodies. $\mathcal{F}$ Neurol Neurosurg Psychiatry 1996;60:388-92.

15 Kimura J. Electrodiagnosis in diseases of nerve and muscle: principles and practice: Philadelphia: FA Davis, 1989.

16 Ad Hoc Subcommittee of the American Academy of Neurology AIDS Task Force. Research criteria for diagnosis of chronic inflammatory demyelinating polyneuropathy (CIDP). Neurology 1991;41:617-8.

17 Moll JWB, Antoine JC, Brashear HR, et al. Guidelines on the detection of paraneoplastic anti-neuronal antibodies. Neurology 1995;45:1937-41.

18 Antoine JC, Mosnier MF, Convers P, et al. Chronic inflammatory demyelinating polyneuropathy associated with carcinoma. I Neurol Neurosurg Psychiatry 1996;60:188-90.

19 Antoine JC, Mosnier JF, Honnorat J, et al. Paraneoplastic demyelinating neuropathy, subacute sensory neuronopathy and anti-Hu antibodies. Clinicopathological study of an autopsy case. Muscle Nerve 1998:21;850-7.

20 Antoine JC, Honnorat J, Vocanson C, et al. Posterior uveitis, paraneoplastic encephalomyelitis and auto-antibodies reparaneoplastic encephalomyelitis and auto-antibodies re-
acting with a developmental protein of brain and retina. $\mathfrak{f}$ Neurol Sci 1993;117:215-23.

21 Quash TT, Rong Y, Belin MF, et al. Molecular cloning of a new unc-33 like c-DNA from rat brain and its relation to paraneoplastic neurological syndromes. Molecular Brain Research 1997;46:329-32.

22 Honnorat J, Aguera M, Zalc B, et al. POP66. A paraneoplastic encephalomyelitis-related antigens, is a marker of adult oligodendrocytes. F Neuropathol Exp Neurol 1998;57:311-22.

23 Dalmau J, Graus F, Rosenblum MK, et al. Anti-Hu associated paraneoplastic encephalomyelitis/sensory neuronopa-
thy. A clinical study of 71 patients. Medicine 1992;71:5972 .

24 Younger DS, Dalmau J, Inghirami G, et al. Anti-Hussociated peripheral nerve and muscle microvasculitis. Neurology 1994;44:181-2.

25 Oh SDI, Dropcho EJ, Claussen GC. Anti-Hu associated paraneoplastic sensory neuronopathy responding to early aggressive immunotherapy: report of two cases and review of literature. Muscle Nerve 1997;20:1576-82.

26 Eggers C, Hagel C, Pfeiffer G. Anti-Hu associated paraneoplastic sensory neuropathy with peripheral nerve demyelination and microvasculitis. F Neurol Sciences 1998;155:178 81.

27 Lucchinetti CF, Kimmel DW, Lennon VA. Paraneoplastic and oncologic profiles of patients seropositive for type 1 antineuronal nuclear autoantibodies. Neurology 1998;50: antineur $652-7$.

28 Oh SDI, Slaughter R, Harlem L. Paraneoplastic vasculitic neuropathy: a treatable neuropathy. Muscle Nerve 1991;14: $152-6$.

29 Rae Grant AD, Feasby TE, Brown XF, et al. A reversible demyelinating polyradiculoneuropathy associated with cancer. Neurology 1986;36(suppl 1):81.

30 Peterson K, Forsyth PA, Posner JB. Paraneoplastic sensorimotor neuropathy associated with breast cancer. $f$ Neurooncol 1994;21:159-70.

31 Yamada M, Shintani S, Mitani $\mathrm{K}$, et al. Peripheral neuropathy with predominantly motor manifestations in a patient

32 O’Neill JH, Murray NMF, Newsom-Davis J. The Lambert Eaton myasthenic syndrome. A review of 50 cases. Brain 1988;111:577-96.

33 Bird SDI, Brown MJ, Shy ME, et al. Chronic inflammatory demyelinating polyneuropathy associated with malignant melanoma. Neurology 1996;46:822-4.

34 Engel AG, Hohlfeld R, Baker BQ. Inflammatory myopathies. In: Engel AG, Franzini-Armstrong C, eds. Myology. New York: McGraw-Hill, 1994; II:1335-83.

35 Prineas J. Polyneuropathies of undetermined cause. Acta Neurol Scand 1970;46(suppl 44):1-72.

36 Halls J, Bredkjaer C, Friis ML. Guillain-Barre syndrome: diagnostic criteria, epidemiology, clinical course and prognosis. Acta Neurol Scand 1988;78:118-22.

37 The Italian Guillain-Barré Study Group. The prognosis and main prognostic indicators of Guillain-Barré syndrome. A multicentre prospective study of 297 patients. Brain 1996; 119:2053-61

38 Barhon RJ, Kissel JT, Warmolts JR, et al. Chronic inflammatory demyelinating polyneuropathy. Clinical characteristics, course, and recommendations for diagnosis criteria. Arch Neurol 1989;46:878-84.

39 Gorson KC, Allam G, Ropper AH. Chronic inflammatory demyelinating polyneuropathy; clinical features and response to treatment in 67 consecutive patients with and without a monoclonal neuropathy. Neurology 1997;48:321- 
40 Vincent D, Dubas F, Hauw JJ, et al. Microvasculites nerveuses et musculaires: 50 cases. Rev Neurol 1985;141: nerveuses

41 Vincent D, Dubas F, Haw JJ, et al. Nerve and muscle microvasculitis. F Neurol Neurosurg Psychiatry 1986;49:1007-10. 42 Harati Y Niakan E. The clinical spectrum of inflammatoryangiopathic neuropathy. $\mathcal{F}$ Neurol Neurosurg Psychiatry 1986;49:1313-16.

43 Fagius J. Chronic cryptogenic polyneuropathy. The search for a cause. Acta Neurol Scand 1983;67:173-80.
44 McLeod JG, Tuck RR, Pollard JD, et al. Chronic polyneuropathy of undetermined cause. $\mathcal{F}$ Neurol Neurosurg Psychiatry 1984;47:530-5.

45 Notermans NC, Wokke JHJ, van der Graaf Y, et al. Chronic idiopathic axonal polyneuropathy: a five year follow up. $\mathcal{F}$ Neurol Neurosurg Psychiatry 1994;57:1525-7.

46 Camerlingo M, Nemni R, Ferraro B, et al. Malignancy and sensory neuropathy of unexplained cause. A prospective study of 51 patients. Arch Neurol 1998;55:981-4.

\section{NEUROLOGICAL STAMP}

\section{Armauer Gerhard Heinrik Hansen (1841-1912)}

Armauer Hansen of Bergen, the leading authority of his time on leprosy, first identified the leprosy bacillus in Norway where the disease was endemic. Leprosy had been thought to be a hereditary affliction. Hansen concluded from epidemiological studies that it was infectious and that the rod shaped bacilli he observed (in 1873) were the cause of leprosy. His claim was not acknowledged for many years. Hansen never managed to fulfil the postulates of Robert Koch and transmit the disease to animals or men using the bacilli. This difficulty was also met with by later workers. Hansen was forced to resign from the Bergen Leprosy Hospital in 1880 after injudiciously injecting live leprosy bacilli into a patient without first obtaining her permission. Nevertheless, he carried on with his own research. By implementing a policy of limited isolation he succeeded in reducing the Norwegian incidence of leprosy from 2833 cases in 1850 to 140 in 1923 . He was honoured philatelicaily by France in 1973 on the centenary of the identification of the leprosy bacillus (Stanley Gibbons 2013, Scott 1379).

L F HAAS

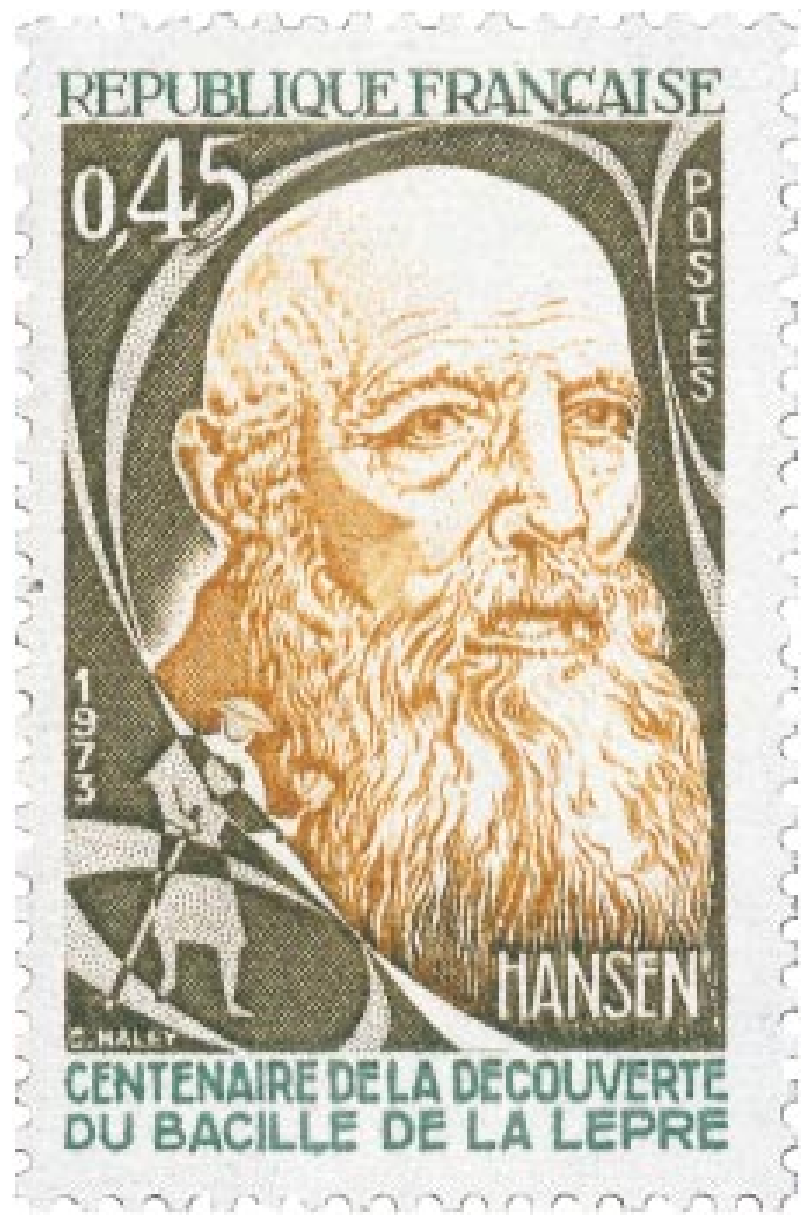

